Information Management and Business Review

Vol. 4, No. 8, pp. 434-443, Aug 2012 (ISSN 2220-3796)

\title{
The Relationship between Work Satisfaction and Service Satisfaction in Perspective of Financial Specialist-Customer Relationship
}

\author{
Chun-Chu Liu*, Li-min Chuang, Chien-min Huang \\ Graduate School Business and operation management, Chang Jung Christian University, \\ *lcc@mail.cjcu.edu.tw
}

\begin{abstract}
This study is based on customer relationship management (CRM). The purpose of the study is to explore the relationship between customer relationship and job satisfaction of financial specialists in perspective of customer treatment satisfaction. The study on customer relationship is divided into five aspects, which are awareness, exploration, expansion, commitment, and dissolution. Job satisfaction is divided into two aspects including internal and external satisfaction. The relationship of the aspects is studied through questionnaires, descriptive statistics, and multiple regression analysis. Results show that CRM and the financial specialist's satisfaction have significant effects to the financial specialists and customer relationship and the financial specialists and customers satisfaction. Therefore, we would propose to the decision-makers of banks the following recommendations on enforcement of CRM in banks and increase of the financial specialist's work satisfaction.
\end{abstract}

Keywords: CRM, Relationship marketing, work satisfaction, Customer service satisfaction

\section{Introduction}

Sixteen new banks and fourteen holding companies have been setup along with the liberation and reformation of financial regulations, which has a great impact on the financial environment in Taiwan. In such a competitive environment, financial industry builds up the capability for independent financial product innovation and greater flexibility in product combination and strategy for diversified development of financial business. It also effectively converts price competition to quality service, thereby enhancing the profitability of the bank, which evidencing the spirit of establishing the financial holding company and the ultimate effort from the government. While facing the unprecedented challenge, with the declining interest rate of NT Dollar, reduction in savings rate spread and pressure of lowering Non-performing Loan (NPL), we have recognized the importance of developing low-risk high-income instruments. Therefore, naturally, wealth management has become the focus of this competition. Citibank had introduced the concept of wealth management in 2001, which was the germination of financial management in Taiwan. Since then, various financial instruments had been promoted in 2003. The term "wealth management" has become the weapon of domestic and foreign banks to develop consumer finance. Focus on the rapid development of wealth management, how to enhance customer loyalty in the shortest time is possibly the key to success of the banking industry. The study starts from the banking wealth management through the questionnaire survey to investigate the three aspects correlation of service quality, customer satisfaction and customer loyalty in order to facilitate bank employees to identify business direction and to create a win-win situation for financial consultant, customers and banks. The scope of this study is targeted on Tainan City and Tainan County. In addition, the design of the questionnaire in addition to referring to the relevant literature refers to the advanced opinions of banking industry for its credibility. According to previous references and the suggestions from experts, the research has set 5 dimensions that included awareness, exploration, expansion, commitment, and dissolution; otherwise, Job satisfaction was divided into two dimensions, internal and external satisfaction. The questionnaire of the research was designed by these dimensions; furthermore, used Regression Analysis to validate the general structure of the research. Viewpoint of CRM and financial specialist's job satisfaction had obvious influence on the customer relationship and satisfaction of customer service. Carries out bank CRM and the financial specialist's job of satisfaction promotion. 


\section{Literature Review}

CRM Operational Definition: This research adopts the viewpoints of Kalakota and Robinson that CRM is based on three stages of acquisition, enhancement and retention in the customer lifecycle to a build good relationship with customers along with various relationship activities.

Relationship between financial specialists and customer Operational definition: Customer Relationship is derived from the concept of relationship marketing (RM). Relationship marketing has two focuses including soliciting and retaining customers (Christopher et al, 1991). Emphasize that, in addition to the "aggressive tactics," a company must also adopt a "defensive strategy" to minimize customer turnover (Storbacka, et al., 1994). Customer solicitation is based on the precondition and foundation of retaining customers, emphasizing the importance of it (Gronroos, 1995). Relationship marketing can be regarded as a mean of confirming, establishing, maintaining, and strengthening a relationship (Gronroos, 1995). Relationship marketing can be used for business-to-consumer (B2C) and business-to-business (B2B) relationship. Dwyer et al (1987) proposed the five phases of relationship marketing including awareness, exploration, expansion, commitment, and dissolution, in which, each phase implicated "how one party treats the other party in a relationship" and that was known as "customer relationship."

Work satisfaction Operational definition: This research adopts the viewpoints of Warr, Cook and Wall (1979) to define the financial specialist's work satisfaction as the satisfaction to the inner and outer properties of work. The overall work satisfaction is achieved combining these two satisfactions, which includes many items. However, the financial specialist's overall work satisfaction is a kind of psychological and social reaction generated to the work nature, environment, leadership and the policy.

Service satisfaction Operational definition: In general, customer's marketing decision is easily affected by psychological factor. Customer satisfaction is the overall perception of customers on products and services, that is, the overall satisfaction; also, the satisfaction on specific product and service attributes. Doods and Monroe (1985) proposed that customer's purchase intention was customer's behavioral tendency in buying the product. Financial specialists and customer service satisfaction are the subjects of this study.

\section{Methodology}

Research objects: This research was conducted based on all financial specialists and customer at one bank in Tainan. For all basic personal profiles, we obtained by asking in the questionnaire and used them as the basis for the demographic statistic variables when these data are further analyzed. After repetitively reviewed and revised by relevant scholars and experts, this research uses six basic data for financial specialists such as age, educational level, marital status, work title, work department and service year as the variables for demographic statistics for this research. For customer, we use the basic data such as gender, age, educational level, marital status and occupation as the variables for demographic statistics, which will be used together with the demographic statistic variables of financial specialists for conducting the descriptive statistics.

Operational definitions and measurement scales of research variables: With reference to the relevant scholars' literatures, this section will give operational definitions of four variables - CRM, relationship between financial specialists and customers, work satisfaction and service satisfaction and according to the literatures; we will further devise suitable scales for measuring these four variables of this research.

CRM Measurement scales: For the CRM variable measurement, this research uses the definition and the scale given by Kalakota and Robinson and further modifies them according to different research object properties, which are further finalized through repetitive review and revision by scholars and experts. There are 10 questions concerning the scales of the CRM variable and the Likert 5 scales are used, which are strongly disagree, disagree, neither agree nor disagree, agree, and strongly agree.

Relationship between financial specialists and customer Measurement scales: This research adopts the Servqual developed by Parasuraman, Zeithaml and Berry (1988) when they proposed the service quality model (PZB model) to measure the financial specialists and customers relationship. The Servqual mainly 
includes five items: awareness, exploration, expansion, commitment, and dissolution, which are similar to the concepts of the financial specialists and customers relationship. Therefore, based on the Servqual and consult Dwyer et al., (1987), this research finalizes the financial specialists and customers scales after being repetitively reviewed and revised by scholars and experts, which have total 20 questions in 5 different items and use Likert 5 scales which are strongly disagree, disagree, neither agree nor disagree, agree and strongly agree.

Work satisfaction Measurement scales: This research finalizes the scales of the financial specialist's work satisfaction based on the Minnesota Satisfaction Questionnaire (MSQ) developed by Weiss et al., (1967) after being repetitively reviewed and revised by scholars and experts, which includes total 20 questions containing the inner satisfaction items and the outer satisfaction items with aid of the Likert 5 scales, which are strongly disagree, disagree, neither agree nor disagree, agree and strongly agree.

Service satisfaction Measurement scales: Financial specialists and customer service satisfaction are the subjects of this study. Therefore, the method of Zeithaml and Bituer (1996) with the banking industry as the study subject is adopted for measuring service satisfaction with the factors of product quality, service quality, situational factors, personal considerations and price. The Service Satisfaction Scale is repeatedly reviewed and then completed by further referring to the opinions of scholars and experts, including 17 questions with the Likert scale (strongly disagree, disagree, neither agree nor disagree, agree, strongly agree) applied for measurement.

\section{Hypothesis:}

How CRM affects the financial specialists and customers relationship: The mainly point of the CRM is based on customer's needs and take customer's life cycle as an important asset. The target mission is to retain the existing customers and to increase customer satisfaction (Kandell, 2000). Customer relationship management is a strategy; in other words, try to understand and to change the behavior of customers through an action-oriented method in order to solicit new customers, to retain the existing customers and to improve customer's profitability. It is an applied system with the combination of customer service with sales, marketing, and support, which mainly covers marketing, sales and services. "Customer relationship management" is derived from the "relationship marketing" (Ryals and Knox, 2001). "Relationship Marketing" emphasizes one-on-one marketing. An enterprise uses overall resources to understand each customer comprehensively; also, interacts with customers through all channels for improving customer's eternal value. The focus of the CRM theory is on the grasp of every marketing opportunity to reduce customer turnover rate for the purpose of retaining the existing customers and enhancing customer loyalty by providing value-added services.

Hypothesis 1 (H1): CRM has positive and significant effect to the financial specialists and customers relationship

Hypothesis 1-1(H1-1): CRM has positive and significant effect to the awareness in the financial specialists and customers relationship.

Hypothesis 1-1(H1-2): CRM has positive and significant effect to the exploration in the financial specialists and customers relationship.

Hypothesis 1-1(H1-3): CRM has positive and significant effect to the expansion in the financial specialists and customers relationship.

Hypothesis 1-1(H1-4): CRM has positive and significant effect to the commitment in the financial specialists and customers relationship.

Hypothesis 1-1(H1-5): CRM has positive and significant effect to the dissolution in the financial specialists and customers relationship.

How CRM affects the financial specialist's work satisfactions: Weiss et al. (1967) divided work satisfaction into inner, outer and overall satisfactions: (1) Inner satisfaction is the degree of satisfaction obtained by the worker from work in terms of value, responsibility, achievement, social status, occupational position and the opportunity of applying ability.(2) Outer satisfaction is the degree of satisfaction obtained by the worker from work in terms of salary, promotion, interactions with supervisors, subordinates and 
colleagues, company policy and the way it is implemented. (3) Overall satisfaction is satisfaction combining inner and outer satisfactions. Accordingly, a person's work satisfaction is determined by his or her evaluation of the overall work conditions, including work itself, work environment and the company strategy. Robbins (1996) believed that the higher work satisfaction a worker has the more positive attitude the worker has towards his or her work. Seashore and Taber (1975) believed that the antecedent that affects work satisfaction can be categorized into environment and personal trait and the interaction of these two variables will affect the consequential reaction of work satisfaction to persons, organizations and the society.

To modern bank institutions, CRM is no more just a fad or buzzword that was then prevalent. In today's overall environment with fierce competition, the concept of CRM and its mechanism have become the central ideas and operational guidelines for bank institutions. Therefore, many scholars have put CRM as the premise and guidance when studying and investigating the bank industry. Under guidance of CRM, bank institutions should regard as their customers. Moreover, they should regard their staff as internal customers and through internal marketing, they should increase work satisfactions and service qualities. This research will therefore address the following hypotheses:

Hypothesis 2: CRM has positive and significant effect to the financial specialist's work satisfaction.

Hypothesis 2-1: (H2-1): CRM has positive and significant effect to inner satisfaction within the financial specialist's work satisfaction.

Hypothesis 2-1: (H2-2): CRM has positive and significant effect to outer satisfaction within the financial specialist's work satisfaction.

How CRM affects service satisfaction: Customer satisfaction is the overall perception of customers on products and services, that is, the overall satisfaction; also, the satisfaction on specific product and service attributes. Doods and Monroe (1985) proposed that the purchase intention of customer was their behavioral tendency in buying the product. According to the classification of service industry by Lovelock (2001), banking is targeting directly on people with frequent contact, customization, and in-person service provided; therefore, it is a customer-oriented industry with a service procedure in compliance with service quality and efficiency for the improvement of customer satisfaction. Schurr and Ozanne (1985) found that trust would affect consumer's attitudes towards the vendor (such as: loyalty) and behavioral responses (such as: take interaction in the future) Lovelock and Wirtz (2004) thought that customer satisfaction was based on the comparison between the performance of product or service and the expectation of the users. Therefore, higher quality service will have higher positive impact on customer's intension. Regardless of business organizations or bank institutions, their purposes to implement CRM are to increase the customer's satisfaction and loyalty so that they can maintain good relationships with customers to assure their continuous purchases of products and services, which then enable them to make profits for survival. This research will therefore address the following hypotheses:

Hypothesis 3 (H3): CRM has positive and significant effect to service satisfaction.

How the financial specialists and customers relationship affects service satisfaction: Customer relationship marketing is so important partly because we have gradually realized one's lifetime consumption potential is considerable (Ambler and Styler, 2000). For seeking the strategy of successful pursuit of customer retention, an enterprise should predict the value of a customer in the long run instead of focusing on the number of customers (Dawes and Swailes, 1999).

This research will therefore address the following hypotheses:

Hypothesis 4 (H4): The financial specialists and customers relationship has positive and significant effect to medical satisfaction.

Hypothesis 4-1 (H4-1): The awareness in the financial specialists and customers relationship has positive and significant effect to service satisfaction.

Hypothesis 4-1 (H4-2): The exploration in the financial specialists and customers relationship has positive and significant effect to service satisfaction.

Hypothesis 4-1 (H4-3): The expansion in the financial specialists and customers relationship has positive and significant effect to service satisfaction. 
Hypothesis 4-1 (H4-4): The commitment in the financial specialists and customers relationship has positive and significant effect to service satisfaction.

Hypothesis 4-1 (H4-5): The dissolution in the financial specialists and customers relationship has positive and significant effect to service satisfaction.

How the financial specialist's work satisfaction affects service satisfaction: Heskett, Sasser and Hart (1990) pointed out that in an organization; an internal staff is the internal customer of the other staff. Emphasis on the internal service quality can increase the internal customer satisfaction, i.e. staff satisfaction, which in turn will deliver high quality product or service and then increase the external customer satisfaction, i.e. the consumers, who will then increase their customer loyalty to enable the organization to increase its profit and to grow. Schurr and Ozanne (1985) found out that trust could affect a consumer's attitude (e.g. loyalty) to the manufacturer and his or her behavior reaction (e.g. involvement of future interaction). Many researchers have also proved in their researches that communication between the physician and the patient has closely related to trust buildup. If a staff has good work satisfaction, it will have positive effect to his or her service quality and the customer satisfaction is increased accordingly. This research will therefore address the following hypotheses:

Hypothesis 5 (H5): The financial specialist's work satisfaction has positive and significant effect to service satisfaction

Hypothesis 5-1 (H5-1): The financial specialist's inner satisfaction within work satisfaction has positive and significant effect to service satisfaction.

Hypothesis 5-1 (H5-2): The financial specialist's outer satisfaction within work satisfaction has positive and significant effect to service satisfaction.

How the financial specialist's work satisfaction affects the financial specialists and customer's relationship: Bradford, Crant and Phillip (2009) also found out in their researches on trust between the supplier and the customer that work satisfaction has positive and significant effect to trust between the customer and the supplier. As can be seen, staff work satisfaction has positive influential effect to the customer and the business organization members. The higher work satisfaction a staff has, he or she in the meantime will upgrade the relationship with customers. This research will therefore address the following hypotheses:

Hypothesis 6 (H6): The financial specialist's work satisfaction has positive effect to the financial specialistscustomers' relationship.

Hypothesis 6-1-1 (H6-1-1): The financial specialist's inner satisfaction within work satisfaction has positive and significant effect to the awareness in the financial specialists-customers relationship.

Hypothesis 6-1-2 (H6-1-2): The financial specialist's outer satisfaction within work satisfaction has positive and significant effect to the awareness in the financial specialists and customers relationship.

Hypothesis 6-2-1 (H6-2-1): The financial specialist's inner satisfaction within work satisfaction has positive and significant effect to the exploration in the financial specialists and customers relationship.

Hypothesis 6-2-2 (H6-2-2): The financial specialist's outer satisfaction within work satisfaction has positive and significant effect to the exploration in the financial specialists and customers relationship.

Hypothesis 6-3-1 (H6-3-1): The financial specialist's inner satisfaction within work satisfaction has positive and significant effect to the expansion in the financial specialists and customers relationship.

Hypothesis 6-3-2 (H6-3-2): The financial specialist's outer satisfaction within work satisfaction has positive and significant effect to the expansion in the financial specialists and customers relationship.

Hypothesis 6-4-1 (H6-4-1): The financial specialist's inner satisfaction within work satisfaction has positive and significant effect to the commitment in the financial specialists and customers relationship.

Hypothesis 6-4-2 (H6-4-2): The financial specialist's outer satisfaction within work satisfaction has positive and significant effect to the commitment in the financial specialists and customers relationship.

Hypothesis 6-5-1 (H6-5-1): The financial specialist's inner satisfaction within work satisfaction has positive and significant effect to the dissolution in the financial specialists and customers relationship.

Hypothesis 6-5-2 (H6-5-2): The financial specialist's outer satisfaction within work satisfaction has positive and significant effect to the dissolution in the financial specialists and customers relationship. 
Research framework: After defining the research variables and the measurement scales of this research, we further propose the research architecture as shown in Figure 1, which is structured by the hypotheses with the purpose we intend to investigate and achieve and those variables of this research.

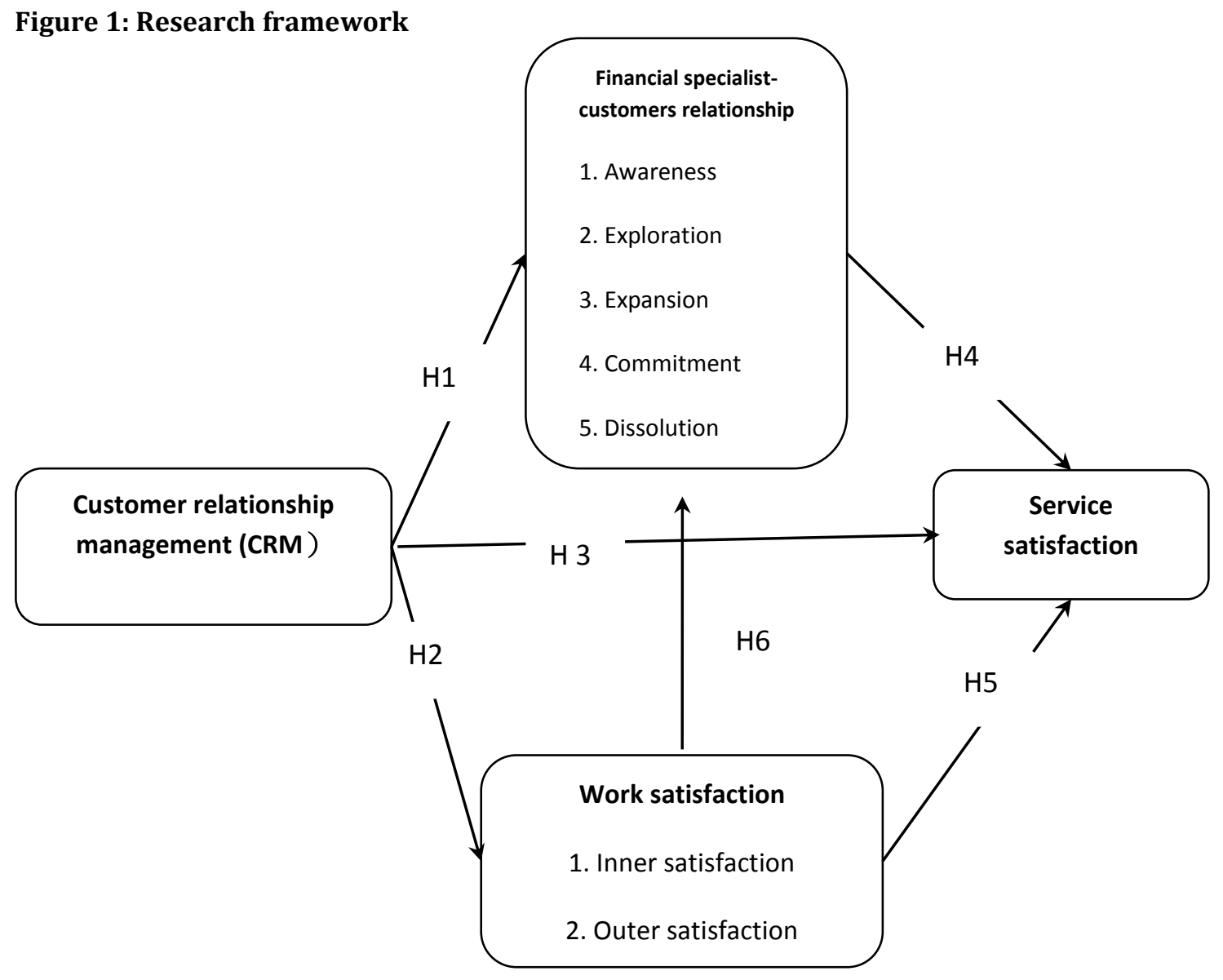

\section{Results}

Sampling structure analysis: The samples used for this research are mainly divided into financial specialists and customers. For financial specialists, most of them are of age at 21 to $30,48 \%$ of total financial specialists, followed by the group of age at 31 to 40 , and $42 \%$ of total financial specialists. For educational level, most of them are of college level, $48 \%$ of all financial specialists, followed by the group of university (college) level, and $32 \%$ of all financial specialists. For marital status, most of them are married, $62 \%$ of all financial specialists. For the work title, most of them are registered officer, accounting for $56 \%$. For service years, most of them are less than 5 years, accounting for 38\%, followed by the group with 11 service years or more, 34\% of all financial specialists. For customers, most of them are women, accounting for $60 \%$. For customer's age, most of them are of age at 31 to $40,32 \%$ of all customers, followed by the groups of age of 21 to 30 and 41 to 50 , accounting for $30 \%$ and $20 \%$, respectively. For educational level, most of them are university (college) level, accounting for $46 \%$ of all customers.

Simple regression analysis on the financial specialists and customers relationship, financial specialist's work satisfaction and customer's service satisfaction viewing from CRM: For the result of regression analysis on the financial specialists and customers relationship and the investigation of effect to the financial specialists and customers relationship viewing from CRM, as listed in Table 1. Overall, except "commitment", CRM has significant effect to awareness, exploration, expansion and dissolution in the financial specialists and customer's relationship. Accordingly, CRM has significant effect to the financial specialists and customers relationship. Therefore, the Hypothesis 1 of this research is established. This also means that CRM 
implemented in the bank has positive effect to increase and enhance the relationship between the financial specialists and customers. Overall, from the result of the regression analysis on the financial specialist's work satisfaction viewing from CRM, CRM has significant effect to the financial specialist's work satisfaction regardless of inner satisfaction or outer satisfaction. Accordingly, the Hypothesis 2 of this research is established. This also means that CRM implemented in the bank has positive effect to increase and enhance the financial specialist's work satisfaction. From the result of the regression analysis on the service satisfaction view from CRM, CRM has significant effect to the service satisfaction $(\mathrm{F}=298.335, \mathrm{P}<0.001)$. Therefore, the Hypothesis 3 is established. This also means that CRM can assist in increasing and enhancing the service satisfaction.

Table 1: Simple regression analysis on the financial specialists and customers' relationship, work satisfaction and customer's service satisfaction

\begin{tabular}{|c|c|c|c|c|c|c|c|c|}
\hline \multirow{2}{*}{$\begin{array}{l}\text { Dependent } \\
\text { variable } \\
\text { Independent } \\
\text { variable }\end{array}$} & \multicolumn{5}{|c|}{ Financial specialists and customers relationship } & \multicolumn{2}{|c|}{ Work satisfaction } & \multirow{2}{*}{$\begin{array}{c}\text { service } \\
\text { satisfaction } \\
(\text { Beta } \\
\text { value })\end{array}$} \\
\hline & $\begin{array}{c}\text { Awareness } \\
\text { (Beta } \\
\text { value }\end{array}$ & $\begin{array}{c}\text { Exploration } \\
\text { (Beta } \\
\text { value) }\end{array}$ & $\begin{array}{c}\text { Expansion } \\
\text { (Beta } \\
\text { value) }\end{array}$ & $\begin{array}{c}\text { Commitment } \\
\text { (Beta } \\
\text { Value) }\end{array}$ & $\begin{array}{c}\text { Dissolution } \\
\text { (Beta } \\
\text { value) }\end{array}$ & $\begin{array}{c}\text { Inner } \\
\text { satisfaction } \\
(\text { Beta } \\
\text { value ) }\end{array}$ & $\begin{array}{c}\text { Medical service } \\
\text { satisfaction (Beta } \\
\text { value) }\end{array}$ & \\
\hline $\begin{array}{l}\text { CRM } \\
\text { viewpoint }\end{array}$ & 0.634 & 0.523 & 0.498 & 0.298 & 0.403 & 0.488 & 0.472 & 0.963 \\
\hline $\mathrm{R}^{2}$ & 0.422 & 0.367 & 0.302 & 0.113 & 0.154 & 0.373 & 0.229 & 0.932 \\
\hline Adjusted R² & 0.411 & 0.394 & 0.258 & 0.097 & 0.167 & 0.289 & 0.284 & 0.875 \\
\hline F value & 35.289 & 22.962 & 15.732 & 3.327 & 9.378 & 22.137 & 13.447 & 298.335 \\
\hline$P$ value & $0.000^{* * *}$ & $0.000^{* * *}$ & $0.000^{* * *}$ & 0.072 & $0.004^{* *}$ & $0.000^{* * *}$ & $0.001^{* *}$ & $0.000^{* * *}$ \\
\hline $\begin{array}{l}\text { Exam. result } \\
\text { of } \\
\text { hypothesis }\end{array}$ & $\begin{array}{l}\text { H1-1 } \\
\text { established }\end{array}$ & $\begin{array}{l}\text { H1-2 } \\
\text { established }\end{array}$ & $\begin{array}{l}\text { H1-3 } \\
\text { established }\end{array}$ & $\begin{array}{l}\text { H1-4 } \\
\text { Not established }\end{array}$ & $\begin{array}{l}\text { H1-5 } \\
\text { established }\end{array}$ & $\begin{array}{l}\mathrm{H} 2-1 \\
\text { established }\end{array}$ & $\begin{array}{l}\mathrm{H} 2-2 \\
\text { established }\end{array}$ & $\begin{array}{l}\text { H3 } \\
\text { established }\end{array}$ \\
\hline
\end{tabular}

Multiple regression analysis on work satisfaction to the financial specialists and customers relationship and service satisfaction, as well as the financial specialists and customers relationship to service satisfaction: For the result of multiple regression analysis on the financial specialist's work satisfaction to the financial specialists and customers relationship and service satisfaction, and the financial specialists and customers relationship to service satisfaction; as well as the investigation of effect of the financial specialist's work satisfaction to the financial specialists and customers relationship and service satisfaction, the financial specialists and customers relationship to service satisfaction view from CRM, as listed in Table 2. The financial specialists and customers relationship has significant effect to service satisfaction. Because among the 5 factors of the financial specialists and customers relationship, only awareness and expansion have significant effect to service satisfaction while the other 3 factors such as exploration, commitment and dissolution have no significant effect to service satisfaction, the Hypothesis 4 of this research is only partially established. The financial specialist's work satisfaction has significant effect to service satisfaction. However, because only one of the two factors of work satisfaction, i.e. inner satisfaction has significant effect to service satisfaction while the outer satisfaction has no significant effect, the Hypothesis 5 of this research is only partially established. Work satisfaction has significant effect to the financial specialists and customers relationship ( $\mathrm{F}=19.437, \mathrm{P}<0.001)$. Because the inner satisfaction within work satisfaction has significant effect to awareness in the financial specialists and customers relationship (P value is 0.002 ), the Hypothesis 6-1-1 is therefore established.

This also means that the inner satisfaction within work satisfaction can assist in increasing awareness in the financial specialists and customer's relationship. However, the outer satisfaction within work satisfaction has no significant effect to awareness in the financial specialists and customers relationship (P values is 0.214). Therefore, the Hypothesis 6-2-1 is not established. This also means that the outer satisfaction within work satisfaction cannot increase awareness in the financial specialists and customer's relationship. As seen from work satisfaction to the exploration in the financial specialists and customers relationship, work satisfaction has significant effect to the exploration in the financial specialists and customers relationship ( $F=18.982$, $\mathrm{P}<0.001$ ). The inner satisfaction within work satisfaction has significant effect to exploration in the financial specialists and customers relationship ( $\mathrm{P}$ value is 0.021). Therefore, the Hypothesis 6-1-2 is established. This 
also means that the inner satisfaction within work satisfaction can assist in increasing exploration in the financial specialists and customer's relationship. In addition, the outer satisfaction within work satisfaction has significant effect to the exploration in the financial specialists and customers relationship (P value is 0.017). Therefore, the Hypothesis 6-2-2 is established. This also means that the outer satisfaction within work satisfaction can assist in increasing exploration in the financial specialists and customer's relationship.

Table 2: Multiple regression analysis on Work satisfaction to the financial specialists and customers' relationship and service satisfaction, and the financial specialists and customers relationship to service satisfaction

\begin{tabular}{|c|c|c|c|c|c|c|c|c|}
\hline \multirow{2}{*}{$\begin{array}{l}\text { Dependent } \\
\text { variable } \\
\text { Independent } \\
\text { variable }\end{array}$} & & \multicolumn{7}{|c|}{ Financial specialists and customers relationship } \\
\hline & & Awareness & Exploration & $\begin{array}{l}\text { Expan- } \\
\text { sion }\end{array}$ & $\begin{array}{l}\text { Commit- } \\
\text { ment }\end{array}$ & $\begin{array}{l}\text { Disso- } \\
\text { lution }\end{array}$ & $\begin{array}{l}\text { service } \\
\text { satisfaction }\end{array}$ & $\begin{array}{l}\text { Service } \\
\text { satisfaction }\end{array}$ \\
\hline \multirow{7}{*}{$\begin{array}{l}\text { Financial } \\
\text { specialist and } \\
\text { customers } \\
\text { relationship }\end{array}$} & $\begin{array}{l}\text { Inner } \\
\text { satisfaction }\end{array}$ & $\begin{array}{l}0.542 \\
\left(0.002^{* *}\right)\end{array}$ & $\begin{array}{l}0.329 \\
\left(0.021^{* *}\right)\end{array}$ & $\begin{array}{l}0.530 \\
\left(0.005^{*}\right)\end{array}$ & $\begin{array}{l}0.463 \\
\left(0.018^{*}\right)\end{array}$ & $\begin{array}{l}0.348 \\
\left(0.041^{*}\right)\end{array}$ & $\begin{array}{l}0.432 \\
(0.027 *)\end{array}$ & \\
\hline & $\begin{array}{l}\text { Outer } \\
\text { satisfaction }\end{array}$ & $\begin{array}{l}0.196 \\
(0.214)\end{array}$ & $\begin{array}{l}0.335 \\
\left(0.017^{* *}\right)\end{array}$ & $\begin{array}{l}0.039 \\
(0.813)\end{array}$ & $\begin{array}{l}-0.009 \\
(0.851)\end{array}$ & $\begin{array}{l}0.239 \\
(0.176)\end{array}$ & $\begin{array}{l}0.079 \\
(0.688)\end{array}$ & \\
\hline & Awareness & & & & & & & $0.503\left(\mathrm{P}=0.008^{* *}\right)$ \\
\hline & Exploration & & & & & & & $0.078(\mathrm{P}=0.685)$ \\
\hline & Expansion & & & & & & & $0.454\left(\mathrm{P}=0.041^{*}\right)$ \\
\hline & Commitment & & & & & & & $-0.231(\mathrm{P}=0.167)$ \\
\hline & Dissolution & & & & & & & $-0.226(\mathrm{P}=0.316)$ \\
\hline \multicolumn{2}{|l|}{$\mathrm{R}^{2}$} & 0.455 & 0.452 & 0.289 & 0.191 & 0.298 & 0.205 & 0.418 \\
\hline \multicolumn{2}{|l|}{ Adjusted $\mathrm{R}^{2}$} & 0.431 & 0.429 & 0.259 & 0.157 & 0.268 & 0.171 & 0.352 \\
\hline \multicolumn{2}{|l|}{$P$ value } & $0.000^{* * *}$ & $0.000^{* * *}$ & $0.000^{* * *}$ & $0.007^{* *}$ & $0.000^{* * *}$ & $0.005^{* *}$ & $0.000^{* * *}$ \\
\hline \multicolumn{2}{|c|}{ Exam. result of hypothesis } & $\begin{array}{l}\text { H6-1-1 } \\
\text { established } \\
\text { H6-1-2 } \\
\text { Not established }\end{array}$ & $\begin{array}{l}\text { H6-2-1 } \\
\text { established } \\
\text { H6-2-2 } \\
\text { established }\end{array}$ & $\begin{array}{l}\text { H6-3-1 } \\
\text { established } \\
\text { H6-3-2 } \\
\text { Not } \\
\text { established }\end{array}$ & $\begin{array}{l}\text { H6-4-1 } \\
\text { established } \\
\text { H6-4-2 } \\
\text { Not } \\
\text { established }\end{array}$ & $\begin{array}{l}\text { H6-5-1 } \\
\text { established } \\
\text { H6-5-2 } \\
\text { Not } \\
\text { established }\end{array}$ & $\begin{array}{l}\text { H5-1 } \\
\text { established } \\
\text { H5-2 } \\
\text { Not } \\
\text { established }\end{array}$ & $\begin{array}{l}\mathrm{H} 4-1, \quad \mathrm{H} 4-3 \\
\text { established ; H4-2, } \\
\mathrm{H} 4-4, \mathrm{H} 4-5 \\
\text { Not established }\end{array}$ \\
\hline
\end{tabular}

As seen from work satisfaction to the financial specialists and customers relationship, the work satisfaction has significant effect to expansion in the financial specialists and customers relationship ( $\mathrm{F}=9.648, \mathrm{P}<0.001)$. The inner satisfaction within work satisfaction has significant effect to the financial specialists and customers relationship ( $\mathrm{P}$ value is 0.005 ). Therefore, the Hypothesis 6-1-3 is established. This also means that the inner satisfaction within work satisfaction can assist in increasing expansion in the financial specialists and customer's relationship. However, the outer satisfaction within work satisfaction has no significant effect to expansion in the financial specialists and customers relationship ( $\mathrm{P}$ value is 0.813 ). Therefore, the Hy pothesis 6-2-3 is not established. This also means that the outer satisfaction within work satisfaction cannot assist in increasing expansion in the financial specialists and customer's relationship. As seen from work satisfaction to commitment in the financial specialists and customers relationship, the work satisfaction has significant effect to commitment in the financial specialists and customers relationship ( $\mathrm{F}=5.376, \mathrm{P}<0.001)$. The inner satisfaction within work satisfaction has significant effect to commitment in the financial specialists and customers relationship (P value is 0.018). Therefore, the Hypothesis 6-1-4 is established. This also means that the inner satisfaction within work satisfaction can assist in increasing commitment in the financial specialists and customer's relationship. However, the outer satisfaction of work satisfaction has no significant effect to commitment in the financial specialists and customers relationship ( $\mathrm{P}$ value is 0.851). Therefore, the Hypothesis 6-2-4 is not established. This also means that the outer satisfaction within work satisfaction cannot assist in increasing commitment in the financial specialists and customer's relationship. Lastly, as seen from work satisfaction to the dissolution in the financial specialists and customers relationship, the work satisfy action has significant effect to dissolution in the financial specialists and customers relationship $(\mathrm{F}=9.764, \mathrm{P}<0.001)$. The inner satisfaction within work satisfaction has significant effect to dissolution in the financial specialists and customers relationship ( $P$ value is 0.041). Therefore, the Hypothesis 6-1-5 is established. This also means that the inner satisfaction within work satisfaction can assist in increasing dissolution in the financial specialists and customer's relationship. However, the outer satisfaction within work satisfaction has no significant effect to dissolution in the financial specialists and customers relationship 
( $\mathrm{P}$ value is 0.176). Therefore, the Hypothesis 6-2-5 is not established. This also means that the outer satisfaction within work satisfaction cannot assist in increasing dissolution in the financial specialists and customer's relationship. Overall, only one factor of the financial specialist's work satisfaction, i.e. inner satisfaction has significant effect to the overall financial specialists and customers relationship while the outer satisfaction has no significant effect. Therefore, the Hypothesis 6 of this research is not established.

\section{Conclusion}

This research investigates from the financial specialist's perspectives the correlations among the financial specialist's work satisfaction, the financial specialists and customers' relationship and the financial specialists and customers' satisfaction viewing from CRM in the banks. As seen from the results, we see that CRM and the financial specialist's satisfaction have significant effects to the financial specialists and customer relationship and the financial specialists and customers satisfaction. Therefore, we would propose to the decision-makers of banks the following recommendations on enforcement of CRM in banks and increase of the financial specialist's work satisfaction.

Enforcement of CRM in banks: For enforcement of CRM in banks, the banks shall continuously create and enhance the customer informational system (CIS) to establish long-term relationship with customers. In addition, through this system, the banks shall understand the financial needs of customers of different attributes and devise customized financial treatment and service for individuals or different potential customer groups; provide suitable financial plan and maintain a good financial specialists and customers relationship. Moreover, under limited resources and the impact of fierce competition, the banks shall also cooperate with other industry through alliance or chain-linkage service to provide customers with holistic, suitable for all ages and high quality service treatment. Lastly, the banks shall implement the CRM philosophy in all aspects and build up a customer-first service environment so that the CRM concept can be rapidly adopted and executed in the software, hardware and system of the banks.

Increasing the financial specialist's work satisfaction: Financial specialists account for the highest ratio of the banks staff and they have highest contacts with customers and their family members. Therefore, financial specialists are the most critical persons to deliver the bank CRM philosophy and are very important members in bank operations. As such, their performances and reactions must not be ignored by the decision-makers and management of the banks. The banks shall not only enrich their work scope and extend their involvements to increase their mental attachment and cohesion to the organizations, but also provide them with training and education for their career planning so that they can acquire satisfaction and a sense of stability from their work. In addition, the banks shall provide a good and sound salary incentive program to stimulate them to aggressively dedicate themselves to their work and missions.

\section{References}

Ambler, T. \& Styler, C. (2000). Viewpoint-the future of relational research in international marketing: constructs and conduits. International Marketing Review, 7(6), 492-508.

Bradford, K., Crant, J. \& Phillips, J. (2009). How suppliers affect trust with their customers: the role of salesperson job satisfaction and perceived customer importance. J Market Theor Prac, 17, 389-400.

Christopher, M., Payne, A. \& Ballantyne, D. (1991). Relationship Marketing, London: Butterworth Heinemann.

Dawes. J. \& Swailes, A. (1999). Retention sans frontiers: issues for financial Service retailers. International Journal of Bank Marketing, 17(1), 36-43

Doods, W. B. \& Monroe, K. B. (1985). The effect of brand and price information on subjective product evaluations. Advances in Consumer Research, 12, 85-90.

Dwyer, F. R., Schurr, P. H. \& Oh, S. (1987). Developing buyer-seller relationships. Journal of Marketing, 51, 1127.

Gronroos, C. (1995). Relationship marketing: the strategic continuum. Journal of Marketing Science, 23(4), 252-254.

Heskett, J., Sasser, W. \& Hart, C. (1990). Changing the Rules of the Game. New York: The Free Press, A Division of MacMillan, Inc.

Kalakota, R. \& Robinson, M. (1999). E-Business: Roadmap for Success. 1st ed., Boston: Addison-Wesley. 
Kandell, J. (2000). CRM. ERM, One-to-One Decoding Relationship Management Theory and Technology. Trust Estates.

Lovelock, C. (2001). The dot.com meltdown: what does it mean for teaching and research in services? Managing Service Quality, 11(5), 302-306.

Lovelock, C. \& Wirtz, W. (2004). Services Marketing, People, Technology, Strategy, USA, Pearson Prentice Hall.

Parasuraman, A., Zeithamal, V. A. \& Berry, L. L. (1988). SERVQUAL: a multiple-item scale for measuring consumer perception of service quality. Journal of Retailing, 64, 12-40.

Ryals, L. \& Knox, S. (2001). Cross-Functional Issues in the Implementation of Relationship Marketing Through Customer Relationship Management. European Management Journal, 19(5), 534-542.

Robbins S. P. (1996). Organizational Behavior, Englewood Cliffs, New Jersey Prentice-Hall International Inc.

Seashore, S. E. \& Taber, T. D. (1975). Job satisfaction and their correlation. American Behavior \& Scientist, 18, 346-368.

Schurr, P. H. \& Ozanne, J. L. (1985). Influences on Exchange Processes: Buyers' Preconceptions of a Seller's Trustworthiness and Bargaining Toughness. Journal of Consumer Research, 11, 939-53.

Storbacka, K., Strandvik, T. \& Gronros, C. (1994). Managing customer relations for profit: the dynamics of relationship quality. International Journal of Service Industry Management, 5, 21-38.

Warr, P., Cook, J. \& Wall, T. (1979). Scales for the measurement of some work attitudes and aspects of psychological well-being. J Occupl Psychol, 52, 129-48.

Weiss, D. J., Dawis, R. V., England, G. W. \& Lofquist, L. H. (1967). Manual for the Minnesota Satisfaction Questionnaire. Minneapolis, University of Minnesota, Industrial Relations Center.

Zeithaml, V. A. \& Bitner, M. J. (1996), Services Marketing, McGraw-Hill, New York, NY. 